\title{
Pillar[5]arenes Bearing Amide and Carboxylic Groups as Synthetic Receptors for Alkali Metal Ions
}

\author{
Luidmila S. Yakimova, Dmitry N. Shurpik, Aigul R. Makhmutova, \\ and Ivan I. Stoikov@ \\ Kazan Federal University, A.M. Butlerov Chemical Institute, 420008 Kazan, Russian Federation \\ ${ }^{\circledR}$ Corresponding authorE-mail: ivan.stoikov@mail.ru
}

\begin{abstract}
Pillar[5]arenes bearing amide and carboxylic groups have demonstrated recognition performance for some representative alkali metal ions including $\mathrm{Li}^{+}, \mathrm{Na}^{+}, \mathrm{K}^{+}$and $\mathrm{Cs}^{+}$in series cations of s-and d-metals compared to pillar [5] arenes with hydroxyl, methoxy and acetone fragments. Their complexation abilities toward these cations were evaluated by UV-Vis technique. The complexation results revealed that pillar[5]arene, containing glicylglicyne groups, were the most efficient cation receptors for $\mathrm{Li}^{+}, \mathrm{Na}^{+}, \mathrm{K}^{+}$and $\mathrm{Cs}^{+}$over other synthesized and studied pillar [5] arenes. Introduction of long glycylglycide fragments into macrocycle structure allowed to increase the association constant logarithm in the case of $\mathrm{Li}^{+}$by 2 orders. In addition, in the set of macrocycles, incorporation of the additional amide fragments and carboxyl group into macrocycle structure leads to increasing the binding efficiency with alkali metal cations.
\end{abstract}

Keywords: Pillar[5]arene, synthesis, molecular recognition, heterocycle, macrocycle.

\section{Пиллар[5]арены, содержащие амидные и карбоксильные фрагменты, как синтетические рецепторы на ионы щелочных металлов}

\author{
ᄉ. С. Якимова, А. Н. Шурпик, А. Р. Махмутова, И. И. Стойков ${ }^{\circledR}$ \\ Казанский (Приволюский) федеральный университет, Химический институт им. А.М. Бутлерова, 420008 Казань, \\ Россия \\ ${ }^{\circledR}$ E-mail: ivan.stoikov@mail.ru
}

\begin{abstract}
Пиллар[5]арены, содержащче амидные и карбоксильные группы, продемонстрировали эффективность распознавания катионов щелочных металлов, а именно, $\mathrm{Li}^{+}, \mathrm{Na}^{+}, \mathrm{K}^{+} u \mathrm{Cs}^{+}$, в ряду катионов $\mathrm{s}$ - $\mathrm{u} d$-элементов по сравнению с пиллар[5]аренами, содержащими гидроксильные, метоксильные и ацетоновые фрагментыл. Их способность к комплексообразованию по отношению к этим катионам была оценена методом УФ спектроскопии. Обнаружено, что пиллар[5]арен, содержащий глицилглицидные фрагменты, является наиболее эффективным катионным рецептором в представленном ряду макроциклов по отношению к катионам щзелочных металлов. Введение в структуру макроичикла длинных глицилглицидных фррагментов позволило увеличить логарифм константы ассоциации с катионом лития на два порядка. Кроме того, выявлена закономерность, которая обеспечивает увеличение эффективности связывания данных катионов, а именно, включение в структуру макрочикла дополнительных амидных фрагментов и карбоксильных групп приводит к повышению эффективности связывания.
\end{abstract}

Ключевые слова: Пиллар[5]арен, синтез, молекулярное распознавание, гетероцикл, макроцикл. 


\section{Introduction}

Main achievements of modern supramolecular chemistry are associated with the processes of molecular recognition, self-organization and self-assembly. ${ }^{[1-6]}$ As a rule, a key role in these processes is played by macrocyclic compounds. ${ }^{[7-13]}$ Depending on the size of the cavity, they are able to form host-guest systems, ${ }^{[14-16]}$ leading to the formation of various supramolecular assembles.

Unique shape, the possibility of functionalization and the presence of optical isomerism make the pillar[n]arenes an absolutely new, unique class of macrocyclic receptors. ${ }^{[17]}$ Directional design of the pillar[n]arenes will allow to develop approaches to creating sensors ${ }^{[18]}$ and catalysts of a new generation. ${ }^{[19]}$

Analysis of the literature data showed that the pillar[n]arenes are inclined to form host-guest complexes with both charged and uncharged linear-form molecules. Introduction of such functional groups $-\mathrm{COOH},-\mathrm{NH}_{2}$, $-\mathrm{SH},-\mathrm{N}^{+}\left(\mathrm{CH}_{3}\right)_{3} \mathrm{Br}-,-(\mathrm{O}) \mathrm{P}(\mathrm{OH})_{2},-\mathrm{N}\left(\mathrm{CH}_{2}-\mathrm{CH}_{3}\right)_{2}{ }^{[20]}$ into the structure of pillar[n]arenes increased the selectivity binding and allowed to evaluate their receptor properties. However, there are practically no examples of obtaining pillar[n]arenes containing amide fragments in the literature.

Earlier in our research group, ${ }^{[21-26]}$ it was shown that the functionalization of the pillar[5] arene with amide fragments increases the solubility of compounds in water and promotes self-association and aggregation of the resulting macrocycles. So, we proposed approach to the introduction of ten amide fragments into the pillar[5] arene structure for the purpose of selective recognition of metal ions, by varying the substituents in the amide fragment $(-\mathrm{C}(\mathrm{O})-\mathrm{NH}-\mathrm{R}$ and $\left.-\mathrm{C}(\mathrm{O})-\mathrm{NR}_{2}\right)$.

\section{Experimental}

\section{General}

${ }^{1} \mathrm{H}$ NMR spectra were recorded on the Bruker Avance-400 (400 MHz) spectrometer and ${ }^{13} \mathrm{C}$ and $2 \mathrm{D}$ HSQC NMR spectra were obtained on the impulse spectrometer Bruker Avance-400 (with $100 \mathrm{MHz}$ and $400 \mathrm{MHz}$, respectively). Chemical shifts were determined against the signals of residual protons of deuterated solvent $\left(\mathrm{CDCl}_{3}\right)$. The concentration of sample solutions was 3-5\%.

Attenuated total internal reflectance IR spectra were recorded with Spectrum 400 (Perkin Elmer) Fourier spectrometer.

Elemental analysis was performed with Perkin Elmer 2400 Series II instrument.

The mass spectra were obtained on Bruker Ultraflex III MALDI-TOF instrument using 4-nitroaniline matrix.

Melting points were determined using the Boetius Block apparatus.

Additional control of the purity of compounds and monitoring of the reaction were carried out by thin-layer chromatography using Silica G, $200 \mu \mathrm{m}$ plates, UV 254.

Most chemicals were purchased from Aldrich and used as received without additional purification. Organic solvents were purified in accordance with standard procedures.

\section{Syntheses}

General procedure of the synthesis of the compounds 1 and 2. Initial 1,4-dimethoxypillar[5]arene 1 was obtained from com- mercially available 1,4-dimethoxybenzene by literary method. ${ }^{[26]}$ Further removal of methoxyl protections led to pillar[5]arene 2. ${ }^{[27]}$ For further purification pillar[5]arene was repeatedly washed with chloroform and water.

1,4-Dimethoxypillar [5]arene (1). Product yield 80 \%. M.p. 249 ${ }^{\circ} \mathrm{C}, 248.8{ }^{\circ} \mathrm{C} .{ }^{[11]}$ MALDI-TOF MS $m / z \mathrm{C}_{45} \mathrm{H}_{50} \mathrm{O}_{10}$ : calculated 750.3 $\left[\mathrm{M}^{+}\right]$, found $773.4[\mathrm{M}+\mathrm{Na}]^{+}, 789.5[\mathrm{M}+\mathrm{K}]^{+} .{ }^{1} \mathrm{H} \mathrm{NMR}\left(\mathrm{CDCl}_{3}\right) \delta_{\mathrm{H}}$ ppm: $3.74\left(30 \mathrm{H}, \mathrm{s},-\mathrm{OCH}_{3}\right), 3.76\left(10 \mathrm{H}, \mathrm{s},-\mathrm{CH}_{2}-\right), 6.80(10 \mathrm{H}, \mathrm{s}, \mathrm{ArH})$. Pillar[5]arene (2). Product yield $91 \%$. The decomposition was observed at $230{ }^{\circ} \mathrm{C}$ without melting. MALDI-TOF MS m/z $\mathrm{C}_{35} \mathrm{H}_{30} \mathrm{O}_{10}$ : calculated $610.2\left[\mathrm{M}^{+}\right]$, found $633.1[\mathrm{M}+\mathrm{Na}]^{+}, 649.2$ $[\mathrm{M}+\mathrm{K}]^{+} .{ }^{1} \mathrm{H} \mathrm{NMR}\left(\mathrm{CD}_{3} \mathrm{COCD}_{3}\right) \delta_{\mathrm{H}} \mathrm{ppm}: 3.66\left(10 \mathrm{H}, \mathrm{s},-\mathrm{CH}_{2}-\right), 6.64$ (10H, s, ArH), 7.99 (10H, s, -OH).

Pillar [5] arenes 3-7 were synthesized by literature method. ${ }^{[23,28]}$ General procedure of the synthesis of the compound 8 . To deca(carboxymethoxy)pillar[5] $\operatorname{arene}^{[23]}(0.30 \mathrm{~g}, 0.25 \mathrm{mmol})$ in a round bottom flask, $10 \mathrm{ml}(84 \mathrm{mmol})$ of $\mathrm{SOCl}_{2}$ and catalytic amount of DMF were added. The reaction mixture was refluxed for $18 \mathrm{hrs}$ before full dissolution of decacarboxylic acid. The solvent was removed under reduced pressure. The obtained powder was dissolved in $\mathrm{CH}_{2} \mathrm{Cl}_{2}(10 \mathrm{ml})$ and piperidine $(0.64 \mathrm{~g}, 7.56 \mathrm{mmol})$ and triethylamine $(5 \mathrm{ml}, 36 \mathrm{mmol})$ were added. Reaction mixture was stirring at room temperature during $48 \mathrm{hrs}$ under argon, washed with hydrochloric acid solution $(2 \times 30 \mathrm{ml})$ and water $(2 \times 30 \mathrm{ml})$. The organic layer was separated, dried (mol. sieves, $3 \AA$ ), the solvent was removed under reduced pressure. The residue was crystallized from ethanol as light-yellow powder.

4,8,14,18,23,26,28,31,32,35-Deca-[(N-piperididocarbonyl) methoxy]-pillar[5]arene (8). Product yield $0.35 \mathrm{~g}$ (74\%). M.p. $253^{\circ}$ C. Found: C 67.44; H6.15; N 7.23. Calculated forC ${ }_{105} \mathrm{H}_{140} \mathrm{~N}_{10} \mathrm{O}_{20}$ : C 67.72; H 7.58; N 7.52. MALDI-TOF MS $m / z$ : calculated 1862.0 $\left[\mathrm{M}^{+}\right]$, found $1861.9\left[\mathrm{M}^{+}\right]$. IR $v_{\max } \mathrm{cm}^{-1}: 2945\left(-\mathrm{CH}_{2}^{-}\right), 2883\left(-\mathrm{CH}_{2}^{-}\right)$, $1662(\mathrm{C}(\mathrm{O}) \mathrm{N}=), 1207\left(\mathrm{Ph}-\mathrm{O}-\mathrm{CH}_{2}-\right) .{ }^{1} \mathrm{H}$ NMR $\left(\mathrm{CDCl}_{3}\right) \delta_{\mathrm{H}} \mathrm{ppm}$ : $1.60\left(60 \mathrm{H}, \quad \mathrm{m},-\mathrm{N}\left(\mathrm{CH}_{2}-\mathrm{CH}_{2}\right)_{2} \mathrm{CH}_{2}\right), 3.31\left(2 \mathrm{H}, \mathrm{m},-\mathrm{N}\left(\mathrm{CH}_{2}-\right.\right.$ $\left.\left.\mathrm{CH}_{2}\right)_{2} \mathrm{CH}_{2}\right), 3.69\left(10 \mathrm{H}, \mathrm{m},-\mathrm{N}\left(\mathrm{CH}_{2}-\mathrm{CH}_{2}\right)_{2} \mathrm{CH}_{2}\right), 3.83(10 \mathrm{H}, \mathrm{m}$, $\left.-\mathrm{N}\left(\mathrm{CH}_{2}-\mathrm{CH}_{2}\right)_{2} \mathrm{CH}_{2}\right), 3.92\left(10 \mathrm{H}, \mathrm{s},-\mathrm{CH}_{2}-\right), 4.63(10 \mathrm{H}, \mathrm{d} \mathrm{AB}-$ system $\left.{ }^{2} J_{H H}=13.8 \mathrm{~Hz}, \mathrm{O}-\mathrm{CH}_{2}-\mathrm{C}(\mathrm{O}) \mathrm{N}-\right), 4.70(10 \mathrm{H}, \mathrm{d}$ AB-system $\left.{ }^{2} J_{H H}=13.8 \mathrm{~Hz}, \mathrm{O}-\mathrm{CH}_{2}-\mathrm{C}(\mathrm{O}) \mathrm{N}-\right), 7.42(10 \mathrm{H}, \mathrm{s}, \mathrm{Ar}-\mathrm{H}) .{ }^{13} \mathrm{C} \mathrm{NMR}$ $\left(\mathrm{CDCl}_{3}\right) \delta_{\mathrm{C}}$ ppm: $24.85,25.85,26.57,29.44,42.86,45.87,66.42$, $114.79,128.43,149.31,167.15$.

General procedure of the synthesis of the compound 9. Pillar[5]arene 2 (0.50 g, $2.46 \mathrm{mmol})$ was suspended in $70 \mathrm{ml}$ of acetonitrile containing anhydrous $\mathrm{K}_{2} \mathrm{CO}_{3}(5.00 \mathrm{~g}, 36 \mathrm{mmol})$. The reaction mixture was stirred while refluxing for $20 \mathrm{~min}$. Catalytic amount of KI and bromoacetone (10.10 g, $74 \mathrm{mmol}, 6.2 \mathrm{ml})$ were added to the suspension formed. The reaction mixture was stirred while refluxing for $24 \mathrm{hrs}$. After cooling, the residue from the reaction mixture was filtered off and dissolved in minimum amount of chloroform. An excess of methanol was slowly added to the solution obtained. The solvent was removed under reduced pressure. The residue was filtered and dried at room temperature.

4,8,14,18,23,26,28,31,32,35-Deca-[(propane-2-one)oxy]pillar[5]arene (9). Product yield 2.12 g (76 \%). M.p.: $203{ }^{\circ} \mathrm{C}$. Found: C 66.12; H 6.31. Calculated for $\mathrm{C}_{65} \mathrm{H}_{70} \mathrm{O}_{20}$ : C 66.66; H 6.02. MALDI-TOF MS $m / z$ : calculated $1170.5\left[\mathrm{M}^{+}\right.$], found 1193.7 $[\mathrm{M}+\mathrm{Na}]^{+}, 1209.72[\mathrm{M}+\mathrm{K}]^{+}$. IR $v_{\max } \mathrm{cm}^{-1}: 3002\left(-\mathrm{C}_{\mathrm{Ph}}-\mathrm{H}\right), 2913$ $\left(-\mathrm{CH}_{2}-\right), 1725(\mathrm{C}=\mathrm{O}), 1171\left(\mathrm{C}_{\mathrm{Ph}^{-}}-\mathrm{O}-\mathrm{CH}_{2}-\right) .{ }^{1} \mathrm{H}$ NMR $\left(\mathrm{CDCl}_{3}\right) \delta_{\mathrm{H}}$ ppm: $1.96\left(10 \mathrm{H}, \mathrm{s},-\mathrm{CH}_{3}\right), 3.84\left(10 \mathrm{H}, \mathrm{s},-\mathrm{CH}_{2}-\right), 4.57\left(20 \mathrm{H}, \mathrm{s},-\mathrm{CH}_{2}-\right.$ $\mathrm{C}(\mathrm{O})-), 6.86(10 \mathrm{H}, \mathrm{s}, \mathrm{Ar}-\mathrm{H}) .{ }^{13} \mathrm{C} \mathrm{NMR}\left(\mathrm{CDCl}_{3}\right) \delta_{\mathrm{C}} \mathrm{ppm}: 29.75$, $26.21,73.31,149.01,128.44,114.73,204.81$.

\section{Determination of the stability constant and stoichiometry of the complex by the UV titration}

The UV measurements were performed with "Shimadzu UV-3600" instrument. The $1 \cdot 10^{-3} \mathrm{M}$ solution of metal cations of $s$-elements $\left(\mathrm{Li}^{+}, \mathrm{Na}^{+}, \mathrm{K}^{+}, \mathrm{Cs}^{+}, 10,20,30,40,50,60,70,80,90\right.$, and $100 \mu \mathrm{L}$ ) in methanol was added to $0.1 \mathrm{ml}$ of the solution of recep- 
tors 6-8 $\left(3 \cdot 10^{-5} \mathrm{M}\right)$ in methanol and diluted to final volume of $3 \mathrm{ml}$ with methanol. The UV spectra of the solutions were then recorded. The stability constant and stoichiometry of the complexes were calculated as described elsewhere. ${ }^{[29]}$ Three independent experiments were carried out for each series. Student's $t$-test was applied in statistical data processing.

\section{Job Plots}

Series of the solutions of pillar[5]arene derivatives 6-8 and metal nitrates $\left(\mathrm{LiNO}_{3}, \mathrm{NaNO}_{3}, \mathrm{KNO}_{3}, \mathrm{CsNO}_{3}\right)$ were prepared in methanol. The volume of the host and guest solutions varied from 0.6:2.4 to 2.4:0.6, respectively, with the total concentration of the host $(\mathrm{H})$ and guest $(\mathrm{G})$ being constant and equal to $1 \cdot 10^{-5} \mathrm{M}$. The solutions were used without further stirring. The absorbance $A_{\mathrm{i}}$ of the complexation systems was measured at the maximum absorbance wavelength of the complex. The absorbance values were used to plot a diagram from which maximum the structures of the complexes were deduced. Three independent experiments were carried out for each system.

\section{Results and Discussion}

\section{Synthesis of Pillar[5]arenes $\mathbf{8}$ and $\mathbf{9}$}

The creation of macrocyclic host for the selective recognition of neutral or charge guests is the promising area of organic and supramolecular chemistry. However, the using of paracyclophanes as host molecules for metal ions in the literature is rare. ${ }^{[23]}$ The presence of free hydroxyl groups in the pillar[n]arene structure opens the possibility of their further functionalization.

The main way to create synthetic receptor in supramolecular chemistry is the modification of the macrocyclic platform by suitable fragments providing the certain orientation of the binding sites for selective interaction with the substrate in space. The ability of the host selectively binds the guest molecule is determined by the location in space and the chemical nature of the binding centers. The functionalization of the pillar[5]arene platform by amide fragments containing the carbonyl group (the donor of the electron pairs), and the proton-donor NH fragment is a promising approach to the construction of $p$-cyclophane receptors capable to binding both charged and neutral guests. By varying the substituents at the nitrogen atoms in amide fragment, it is possible to vary their electron donating, steric loading, $\mathrm{NH}$ acidity (in the case of secondary amides), etc.

Earlier, in our scientific group it was shown that the pillar[5]arenes with ten carboxyl (3) ${ }^{[23]}$ or amide fragments (pyrrolidide (6) and morpholide (7) $)^{[23]}$ are capable to bind the alkali metal ions. To evaluate the effect of the substituents structure in the macrocycle platform on the ability to recognize metal ions, this series was expanded both in terms of $(a)$ the substituents variation (1-9), and in terms of $(b)$ the expansion number of metal ions $-s$ - and $d$-elements.

So, we synthesized the series of pillar[5]arenes containing carboxylic, amide and carbonyl fragments, as well as perhydroxylated and permethylated pillar[5]arenes (Figure 1).

To evaluate the influence of the substituent's structure at the amide fragment on the ability to bind metal ions, macrocycles $4{ }^{[28]} 5,{ }^{[28]}$ and $\mathbf{8}$ were synthesized. As initial

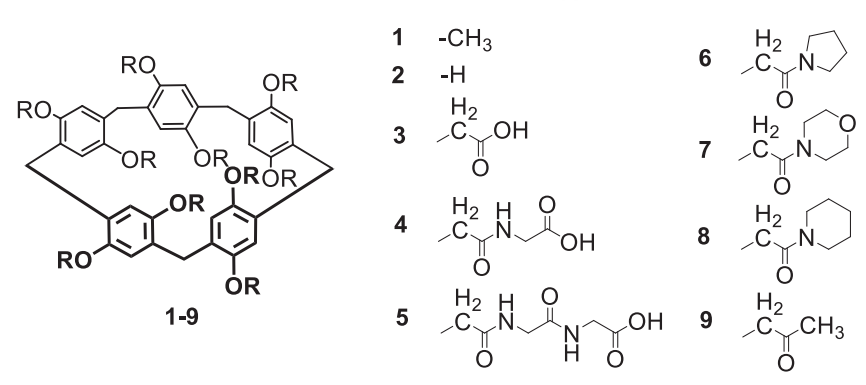

Figure 1. The structures of the studied pillar[5]arenes.

compounds for synthesis of pillar[5]arenes containing ten amide fragments, we used macrocycle $\mathbf{3}$ with ten carboxyl groups. The reaction of the macrocycle 3 (Scheme 1) with a series of tertiary amines (pyrrolidine, ${ }^{[12]}$ morpholine, ${ }^{[23]}$ piperidine), and also with glycine ethyl ester ${ }^{[28]}$ and its dimerglycylglycine ethyl ester ${ }^{[28]}$ was studied. The deca-acid $\mathbf{3}$ was in situ converted into the deca-acid chloride by reaction with $\mathrm{SOCl}_{2}$ in the presence of catalytic amounts of DMF. Further, acylation of the corresponding amines with deca-acid chloride of $\mathbf{3}$ gave compounds $\mathbf{4 - 8}$ in good yields. Owing to the large number of reaction centers in the deca-substituted pillar[5]arenes, the reaction was carried out for 48 hours in anhydrous $\mathrm{CH}_{2} \mathrm{Cl}_{2}$ in the presence of $\mathrm{Et}_{3} \mathrm{~N}$.

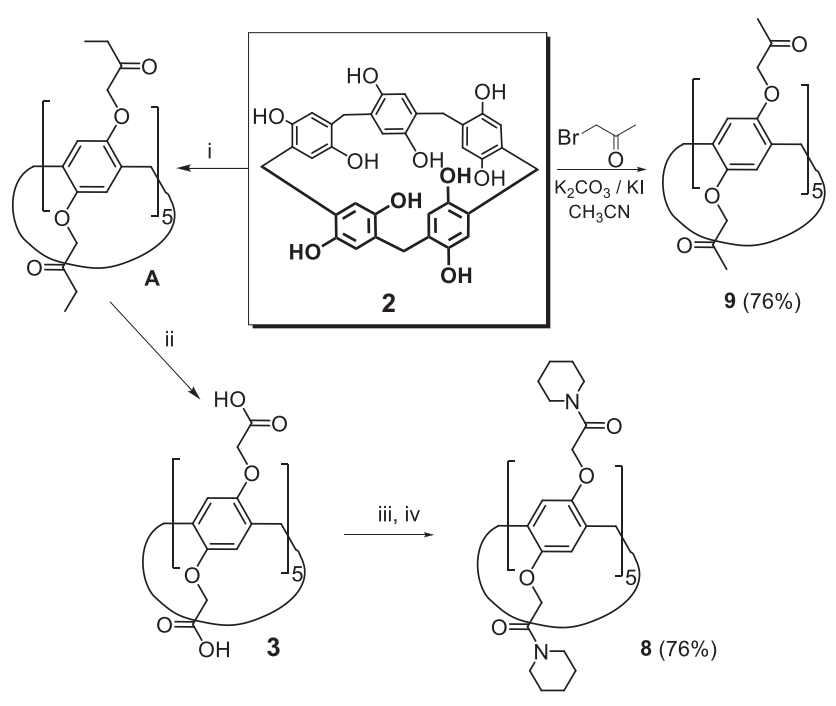

Scheme 1. Reagents and conditions: i - ethyl bromoacetate/ $\mathrm{K}_{2} \mathrm{CO}_{3}$, KI, acetonitrile, reflux; ii - $\mathrm{NaOH}(20 \%)$, THF; iii $-\mathrm{SOCl}_{2}$, reflux; iv - piperidine, $\mathrm{Et}_{3} \mathrm{~N} / \mathrm{CH}_{2} \mathrm{Cl}_{2}$.

Figure 2 shows the ${ }^{1} \mathrm{H}$ NMR spectrum of $\mathbf{8}$, in which aromatic proton signals and methylene bridges appear as singlets at 7.42 and $3.92 \mathrm{ppm}$, correspondingly. It indicates the synthesis of fully acylated product. Interestingly, the chemical shifts and multiplicity of the methylene and aromatic protons are similar to those in calix[n]arene with $\mathrm{n} \geq 6{ }^{[30]}$ The oxymethylene protons were observed as $A B$ spin system (4.63 and $4.70 \mathrm{ppm}$ ) with a spin-spin interaction constant of $13.8 \mathrm{~Hz}$. The piperidide protons appear as multiplets in the field at 3.83 to $1.60 \mathrm{ppm}$. 


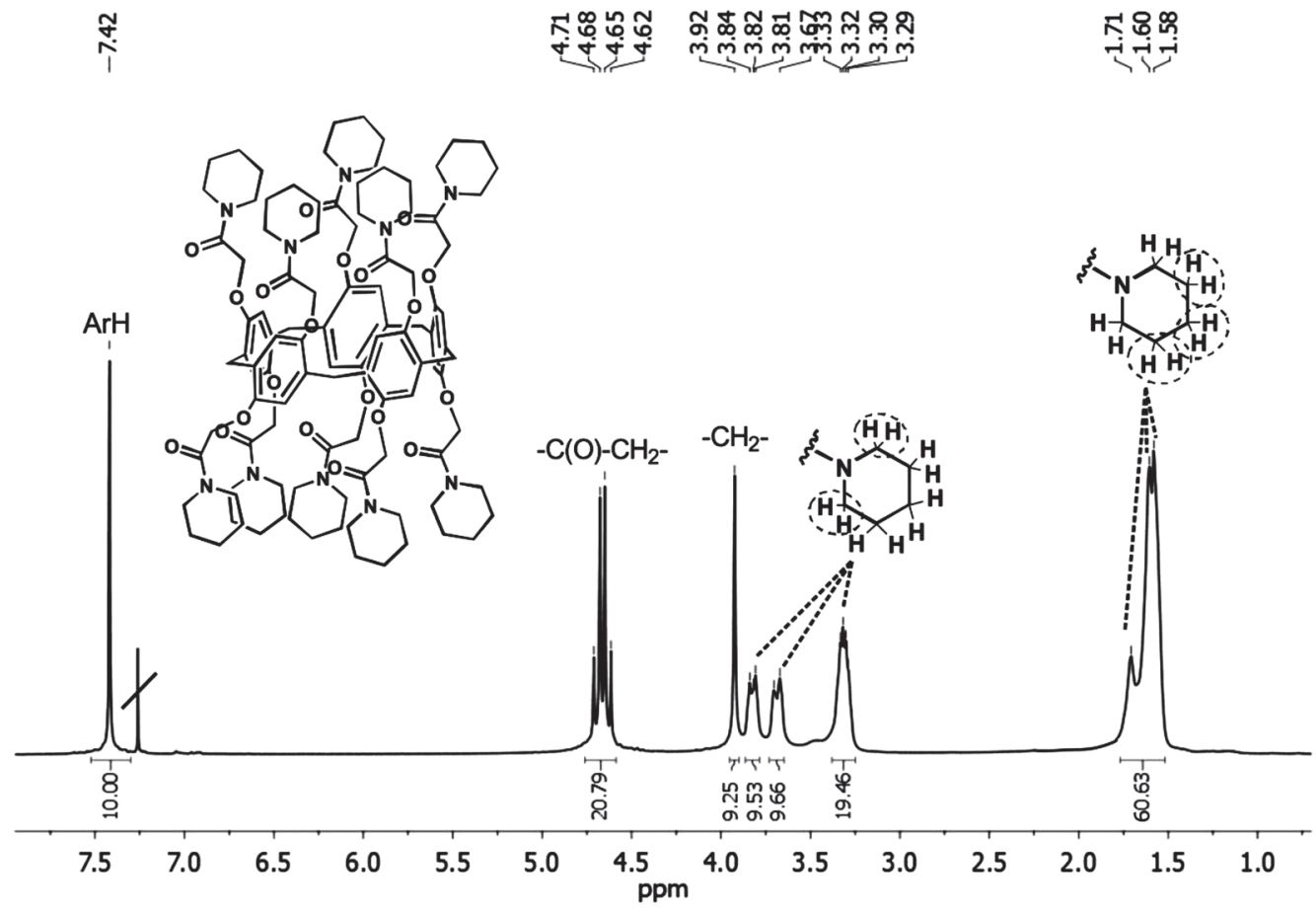

Figure 2. ${ }^{1} \mathrm{H}$ NMR spectrum of compound $\mathbf{8}\left(\mathrm{CDCl}_{3}\right.$, at $25^{\circ} \mathrm{C}$, Bruker Avance-400).

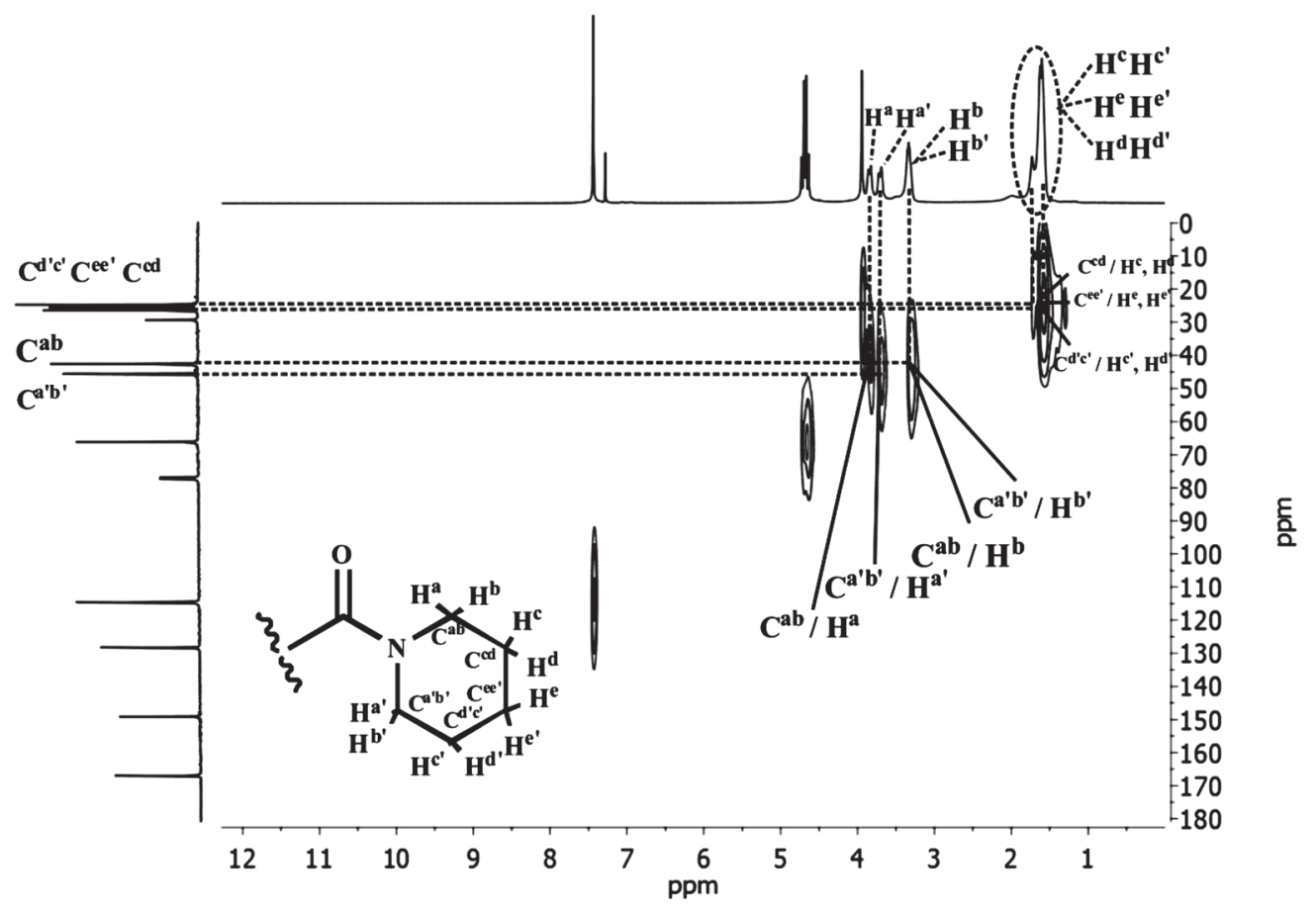

Figure 3. Part of ${ }^{1} \mathrm{H}-{ }^{13} \mathrm{C}$ HSQC NMR spectrum of compound 8 in $\mathrm{CDCl}_{3}$ at $25^{\circ} \mathrm{C}$.

The nonequivalence of the protons can result from the macrocycle chirality. The chemical shifts, integrated intensity and multiplicity of all the proton signals in the ${ }^{1} \mathrm{H}$ NMR spectrum for compound $\mathbf{8}$ are in good agreement with proposed for the structure.

It should be noted that the protons of the piperidide fragments form two four-spin and two six-spin systems with no apparent order. The nonequivalence of piperidide protons is most likely caused by inhibition of the rotation the aryl fragments due to appearance of a bulky substituent and the presence of planar chirality in the pillar[5]arene 8 . Therefore, the assignment of each proton signals and carbons ring is made on the cross peaks ${ }^{1} \mathrm{H}-{ }^{13} \mathrm{C}$ HSQC NMR spectrum (Figure 3 ). In the region of proton resonance of the piperidide fragments 
of $\mathbf{8}$, it is clear that the carbon atoms of piperidide fragments $\mathrm{C}^{\mathrm{d}^{\prime} \mathrm{c}^{\prime}}, \mathrm{C}^{\mathrm{ee}}, \mathrm{C}^{\mathrm{dd}}, \mathrm{C}^{\mathrm{ab}}$, and $\mathrm{C}^{\mathrm{a}^{\prime} \mathrm{b}}$ are not equivalent.

According to the literature data, ${ }^{[31]}$ carbon nuclei $\mathrm{C}^{\mathrm{d} ' \mathrm{c}}$, $\mathrm{C}^{\mathrm{ee}}, \mathrm{C}^{\mathrm{dd}}$ resonate in a more strong field and correspond to the signals of two equivalent protons $\mathrm{H}^{\mathrm{c}^{\prime}}$ and $\mathrm{H}^{\mathrm{d}}, \mathrm{H}^{\mathrm{e}}$ and $\mathrm{H}^{\mathrm{e}}, \mathrm{H}^{\mathrm{c}}$ and $\mathrm{H}^{\mathrm{d}}$, respectively. Carbon signals $\mathrm{C}^{\mathrm{ab}}$ and $\mathrm{C}^{\mathrm{a}^{\mathrm{b}} \mathrm{b}}$ correspond to four signals of nonequivalent protons $\mathrm{H}^{\mathrm{a}}, \mathrm{H}^{\mathrm{b}}$ and $\mathrm{H}^{\mathrm{a}^{2}}, \mathrm{H}^{\mathrm{b}}$. The resonance regions of these protons are overlapped.

The conformational transformations of the decasubstituted symmetric pillar[5] arenes lead to the racemization of the macrocyclic platform due to the rotation of aryl fragments. When the process is slow (hindered rotation), the ${ }^{1} \mathrm{H}$ NMR spectra exhibit a complication of the spectral pattern. ${ }^{[32-35]}$ Characteristics for such dynamic processes are the oxymethylene protons signals $\left(-\mathrm{O}-\mathrm{CH}_{2}-\right)$ in the ${ }^{1} \mathrm{H}$ NMR spectra. Due to the stabilization of the two planar enantiomers of the pillar[5]arene, these protons become diastereomeric and manifest themselves as AB-system. In order to study the effect of secondary and tertiary amide groups, as well as their substituents, on the conformational mobility of the macrocyclic platform, analysis of the spin systems in ${ }^{1} \mathrm{H}$ NMR spectra of compounds 4-8 was carried. In order to exclude or confirm the effect of amide group on the conformational mobility of macrocycles $\mathbf{4 - 8}$, macrocycle 9 with only carbonyl groups is synthesized by original procedure (Scheme 1). Note, this macrocycle is interesting from the standpoint of assessing the effect of the electron donor substitutient at the carbonyl group on the complexing ability with metal cations.

According to the experimental data (Table 1), the highest values of spin-spin coupling constants between oxymethylene protons are for pillar[5] arene $\mathbf{6},{ }^{[23]}$ containing the pyrrolidide fragment. In the case of $\mathbf{4}$ and $\mathbf{5},{ }^{[28]}$ which do not contain cyclic amide fragments, broadened singlet of the oxymethylene protons is observed due to some rotation of the aryl fragments. Free rotation is observed for new compound

Table 1. Characterization of pillar[n]arenes $3-9$ by ${ }^{1} \mathrm{H}$ NMR spectroscopy in $\mathrm{CDCl}_{3}$ at room temperature. The concentration of pillar[n]arenes 3-9 solutions was 3-5\%.

\begin{tabular}{|c|c|c|c|c|}
\hline \multirow{2}{*}{$\begin{array}{l}\text { Com- } \\
\text { pound }\end{array}$} & \multirow[t]{2}{*}{$\mathrm{R}$} & \multicolumn{2}{|c|}{$\begin{array}{l}\text { Spin system } \\
\text { of the protons }\end{array}$} & \multirow{2}{*}{${ }^{3} J_{\mathrm{HH}} / \mathrm{Hz}$} \\
\hline & & $\mathrm{CH}_{2}$ & $\mathrm{OCH}_{2}$ & \\
\hline 3 & & $\mathrm{~A}_{2}(\mathrm{~s})$ & $\mathrm{AB}$ & 15.8 \\
\hline 4 & & $\mathrm{~A}_{2}(\mathrm{~s})$ & $\mathrm{A}_{2}$ (br. s) & - \\
\hline 5 & & $\mathrm{~A}_{2}(\mathrm{~s})$ & $\mathrm{A}_{2}$ (br. s) & - \\
\hline 6 & & $\mathrm{~A}_{2}(\mathrm{~s})$ & $\mathrm{AB}$ & 14.4 \\
\hline 7 & & $\mathrm{~A}_{2}(\mathrm{~s})$ & $\mathrm{AB}$ & 13.8 \\
\hline 8 & & $\mathrm{~A}_{2}(\mathrm{~s})$ & $\mathrm{AB}$ & 13.8 \\
\hline 9 & & $\mathrm{~A}_{2}(\mathrm{~s})$ & $\mathrm{A}_{2}(\mathrm{~s})$ & - \\
\hline
\end{tabular}

9 without amide groups. As expected, ${ }^{[36]}$ the introduction of cyclic fragment into the pillar[5] arene structure decreases the conformational mobility of compounds 6-8. So, the introduction of an amide groups promotes the stabilization of the planar enantiomers of the pillar[5]arenes.

Thus, new pillar[5] arenes containing piperidide 8 and carbonyl fragments 9 were synthesized. The structure of the compounds obtained was characterized by ${ }^{1} \mathrm{H}$ NMR, ${ }^{13} \mathrm{C}$, IR spectroscopy and mass spectrometry (MALDI-TOF). The spatial structure of new functionalized pillar[5]arene $\mathbf{8}$ was established by ${ }^{1} \mathrm{H}-{ }^{13} \mathrm{C}$ HSQC spectroscopy.

\section{Complexation Study of the Synthesized Pillar[5] arenes 1-9 by UV-Vis Spectroscopy}

To evaluate the effect of the substituents structure in the macrocycle platform on the ability to recognize metal ions, pillar[5]arenes 1-9 were investigated. The metal ion recognition abilities of pillar[5] arenes $\mathbf{1}-\mathbf{9}$ were evaluated by UV-Vis spectroscopy. Seven metal cations were employed in the study including $s$-elements $\left(\mathrm{Li}^{+}, \mathrm{Na}^{+}, \mathrm{K}^{+}, \mathrm{Cs}^{+}\right)$and $d$ elements $\left(\mathrm{Ag}^{+}, \mathrm{Cu}^{2+}, \mathrm{Fe}^{3+}\right)$. Changes in the absorbance spectrum of the pillar[5] arenes after addition of the nitrates of metals indicated the formation of their complexes with the substrates. The interaction between metal ions and pillar[5] arenes 1-9 in methanol monitored by UV-Vis spectroscopy showed significant changes in the absorbance spectrum of the macrocycles only after the addition of $\mathrm{Li}^{+}, \mathrm{Na}^{+}, \mathrm{K}^{+}, \mathrm{Cs}^{+}$ to macrocycles 3-8. The hyperchromic effect was observed at $200-250 \mathrm{~nm}$ (Figure 4).

Despite the fact that phenolic oxygen atoms in macrocycles $\mathbf{1}$ and $\mathbf{2}$ have two lone electron pairs that can promote the binding of metal cations, there is no complexation. Obviously, it is due to the $+\mathrm{M}$-effect of the $-\mathrm{OH}$ and $-\mathrm{OCH}_{3}$ groups, which causes delocalization one lone oxygen pairs. In addition, cations of $d$-elements do not bind by any of the macrocycles studied. According to HSAB concept, soft acids predominantly interact with soft bases, and hard acids with hard bases. Alkali metal ions are hard acids, unlike cations of $d$-elements (soft acids). Macrocycles 3-9 contain a carbonyl group with substituents of different structures. All these macrocycles, except pillar[5]arene 9, form complexes with alkali metal ions according to HSAB concept. The macrocycle 9, in contrast to the macrocycle $\mathbf{3}$, does not form complexes with the $s$-element cations, despite the fact that it contains a hard base (oxygen of carbonyl group). Apparently, the strong electron-donating effect of the substituent $(\mathrm{OH}$ group) in macrocycle 3 compared to macrocycle $9\left(-\mathrm{CH}_{3}\right.$ group) promotes the increase of charge on the oxygen atom at carbonyl group, which creates favorable conditions for the formation of the complex.

To quantify molecular recognition the alkali metal ions by pillar[5]arenes $\mathbf{4 , 5}$ and $\mathbf{8}$, the stability constants and the stoichiometry of the macrocycle-substrate complexes formed in the methanol were established (Table 2). Further information on the metal ions binding stoichiometry of pillar[5] arenes 4-6 was obtained from Job's plot. The Figure 5 shows the results for $\mathbf{5}+\mathrm{Li}^{+}$complexation at $215 \mathrm{~nm}$. The maximum point of the mole fractions was found to be about 0.5 , suggesting a ligand-metal ratio of $1: 1$ in the 


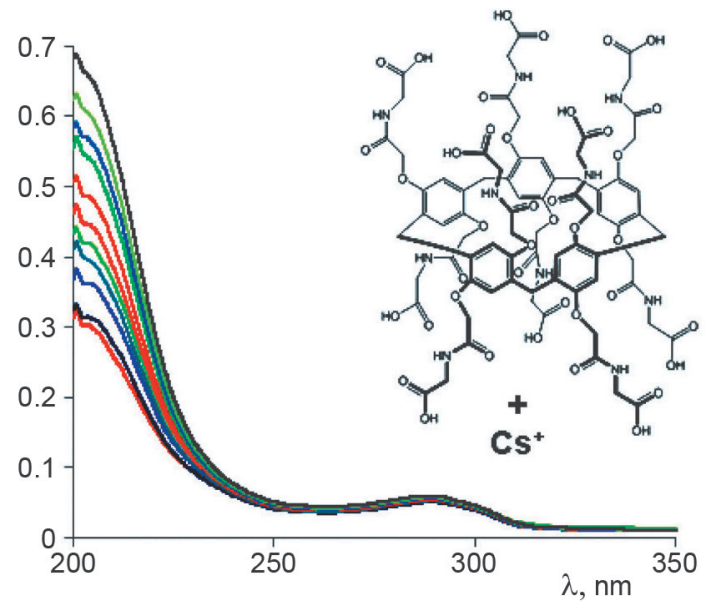

Figure. 4. Spectrophotometric titration of the system pillar[5]arene $\mathbf{4}$ and $\mathrm{Cs}^{+}$in methanol.

complex. Similarly, to that, all the systems studied formed the 1:1 complexes. Using the same method, the binding stoichiometry coefficients of pillar[5]arene/metal ions were also obtained as a ligand-metal ratio of 1:1 in the complex.

The $\lg K_{a s s}$ values of the complexes obtained varied between 1.69 and 4.96. Analysis of the experimental data showed that the association constants logarithms $\left(\lg K_{a s s}\right)$ are close for macrocycles $\mathbf{3}, \mathbf{6}$ and $\mathbf{7}$ and slightly lower than those for macrocycle 8. However, in the case of macrocycles $\mathbf{4}$ and $\mathbf{5}$, the $\lg K_{\text {ass }}$ value increases by 1-2 orders with respect to all alkali metal cations. So, the pillar[5] arene 5, containing glycylglycide fragments showed the most effective complexing ability with respect to all the $s$-elements studied: $\lg K_{\text {ass }}$ are in the range from 4.96 for $\mathrm{Li}^{+}$to 3.51 for $\mathrm{Cs}^{+}$. Obviously, this is due to the structure of the substituent at the nitrogen atom of the amide group. An increase in the electron-donating of the substituent upon transition from macrocycles 6,7 to macrocycles 4,5 leads to increase the negative charge on the oxygen atom in amide fragment, which affects the binding efficiency, namely, the $\lg K_{a s s}$ values. Note, analogous effect of the substituent is also manifested in the case of compounds 7 and 8 : the presence of an additional electron donor (an oxygen atom) in the cyclic fragment of the substituent increases the binding efficiency.

In the case of macrocycle $\mathbf{5}$, effective binding of all alkali metals ions is observed. Obviously, this corresponds not only to the HSAB principles, which are realized in other macrocycles with amide and carboxyl moieties. Preliminary modeling showed ${ }^{[37]}$ that the ions of $\mathrm{Li}^{+}, \mathrm{Na}^{+}, \mathrm{K}^{+}$can be placed in the pillar[5]arene cavity, and $\mathrm{Cs}^{+}-$is not because of too large cation size. Surprisingly, $\lg K_{\text {ass }}$ for complex 5/ $\mathrm{Cs}^{+}$is 1-fold higher than for other macrocycles. Apparently, in this case, an additional factor is the distance between the coordination centers and macrocyclic platform, which is
A)

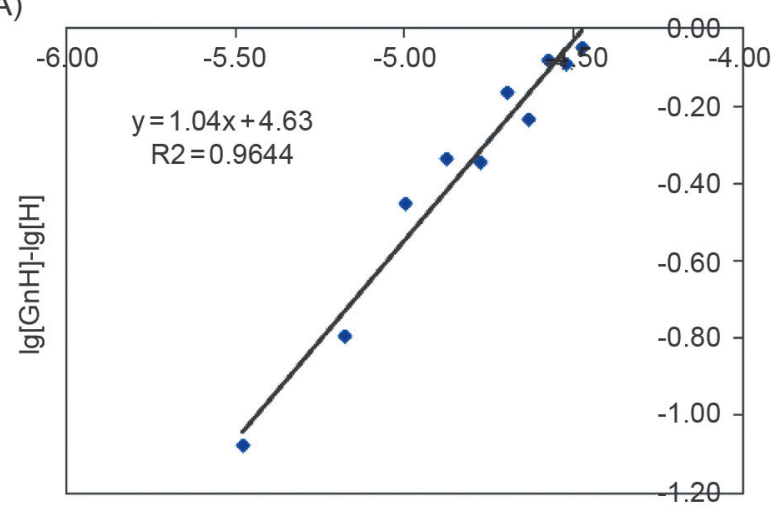

$\lg [\mathrm{G}]$
B)

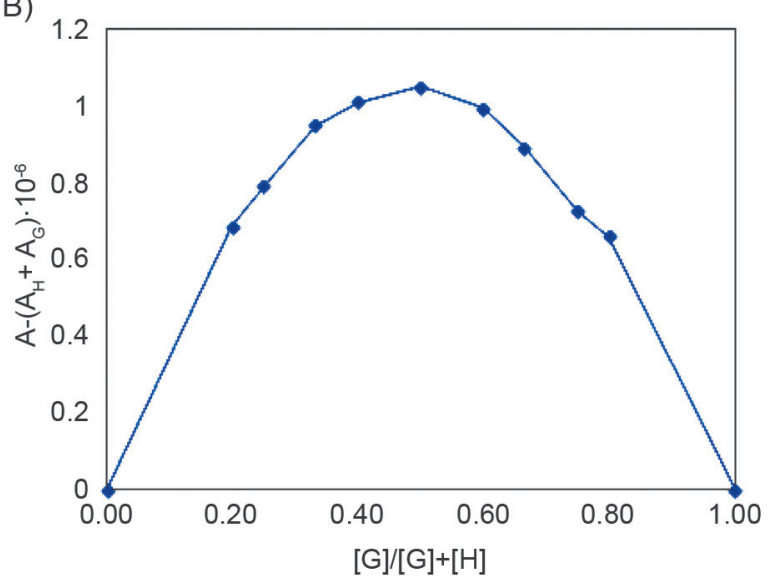

Figure. 5. (A) The titration curve at $215 \mathrm{~nm}$ for system $\mathbf{5}^{+} \mathrm{Li}^{+}$(the concentration of pillar[n]arenes $\mathbf{5}$ solution is $C=1 \cdot 10^{-6} \mathrm{M}$, the concentration of $\mathrm{Li}^{+}$solution is varied from $3.3 \cdot 10^{-6} \mathrm{M}$ to $3.3 \cdot 10^{-5} \mathrm{M}$ ). (B) The Job's plot for the determination of the stoichiometry in the complex (total concentration of the host $(\mathrm{H})$ and guest $(\mathrm{G})$ is constant and equals to $1 \cdot 10^{-5} \mathrm{M}$ ).

Table 2. Association constants $\left(\lg K_{a s s}\right)$ for the complexation of pillar[5] arenes 3-8 with metal ions of $s-\left(\mathrm{Li}^{+}, \mathrm{Na}^{+}, \mathrm{K}^{+}, \mathrm{Cs}^{+}\right)$elements in methanol at $298 \mathrm{~K}$. The concentration of pillar[n]arenes $3-\mathbf{8}$ solutions is constant $\left(C=1 \cdot 10^{-6} \mathrm{M}\right)$, the concentration of cation solutions is varied from $3.3 \cdot 10^{-6} \mathrm{M}$ to $3.3 \cdot 10^{-5} \mathrm{M}$.

\begin{tabular}{ccccc}
\hline \multirow{2}{*}{ Host } & \multicolumn{3}{c}{$\lg K_{\text {ass }}$} \\
\cline { 2 - 5 } & $\mathrm{Li}^{+}$ & $\mathrm{Na}^{+}$ & $\mathrm{K}^{+}$ & $\mathrm{Cs}^{+}$ \\
\hline $\mathbf{3}^{[12]}$ & $3.33 \pm 0.11$ & $2.67 \pm 0.18$ & $2.71 \pm 0.13$ & $2.52 \pm 0.16$ \\
$\mathbf{4}$ & $4.67 \pm 0.17$ & $3.71 \pm 0.19$ & $3.26 \pm 0.19$ & $2.62 \pm 0.15$ \\
$\mathbf{5}$ & $4.96 \pm 0.13$ & $4.81 \pm 0.15$ & $4.09 \pm 0.18$ & $3.51 \pm 0.20$ \\
$\mathbf{6}^{[12]}$ & $3.53 \pm 0.11$ & $2.19 \pm 0.16$ & $2.78 \pm 0.12$ & $2.31 \pm 0.14$ \\
$\boldsymbol{7}^{[12]}$ & $3.60 \pm 0.07$ & $2.15 \pm 0.02$ & $2.46 \pm 0.17$ & $2.45 \pm 0.12$ \\
$\mathbf{8}$ & $2.98 \pm 0.17$ & $2.27 \pm 0.05$ & $2.06 \pm 0.20$ & $1.69 \pm 0.28$ \\
\hline
\end{tabular}


maximal in the case of macrocycle 5 . According to ${ }^{1} \mathrm{H}$ NMR data, macrocycle $\mathbf{5}$ is characterized by slow rotation, which is due to cyclic H-bonds formed by carboxyl and amide fragments. Moreover, in the case of the macrocycle 5, in comparison with macrocycles 3, 4 and 6-8, the amount of these bonds is maximized. Such structure with a pseudocavity for binding large-sized guests ensures the effective complexation of the largest cation in this series $-\mathrm{Cs}^{+}$. Thus, with introduction of the long glycylglycid fragments into the macrocyclic structure, it became possible to bind cations that do not fit the size of the cavity of macrocyclic platform.

In general, in the series of cations (from $\mathrm{Li}^{+}$to $\mathrm{Cs}^{+}$), a decrease in the binding efficiency is observed, which is probably due to the increase in the cation size and decrease in its rigidity.

The results obtained agree with those from molecular simulation $^{[37]}$ of the pillar[5] arene derivatives complexes with metal cations, where a weak non-selective interaction with a series of guests was found.

\section{Conclusion}

In summary, symmetric hosts - pillar[5] arenes containing ten carboxylic, piperidide, morpholide, pyrrolidide, glicyl and glycylglycide, carbonyl units - were synthesized and its complexation towards the $s$-elements cations $\left(\mathrm{Li}^{+}\right.$, $\left.\mathrm{Na}^{+}, \mathrm{K}^{+}, \mathrm{Cs}^{+}\right)$and $d$-elements $\left(\mathrm{Ag}^{+}, \mathrm{Cu}^{2+}, \mathrm{Fe}^{3+}\right)$ investigated by UV-Vis spectroscopy. All these macrocycles, except pillar[5] arenes 1, 2, 9, form complexes with alkali metal ions. Significant changes were not found in the binding capability toward cations of $d$-elements. The values of the association constants $\left(10^{2}-10^{5} \mathrm{M}^{-1}\right)$ of the complexes obtained by derivatives of the pillar[5] arenes 3-8 with alkali metal cations with 1:1 stoichiometry were determined by electron spectroscopy. It was observed, the strong electron-donating effect of the substituent at carbonyl group in row of macrocycle 3-9 promotes favorable conditions for the formation of the complex. Note, the long glycylglycide fragments in macrocycle structure 5 allowed to increase the association constant logarithm with $\mathrm{Li}^{+}$by 2 orders.

Acknowledgements. The work was supported by Russian Scientific Fond (No. 17-13-01208).

\section{References}

1. Leininger S., Olenyuk B., Stang P.J. Chem. Rev. 2000, 100, 853-908.

2. Gorbachuk V.V., Yakimova L.S., Mostovaya O.A., Bizyaev D.A., Bukharaev A.A., Antipin I.S., Konovalov A.I., Zharov I., Stoikov I.I. Silicon 2011, 3(1), 5-12.

3. Yang L., Tan X., Wang Z., Zhang X. Chem. Rev. 2015, 115, 7196-7239.

4. Sayed M., Pal H. J. Mater. Chem. C 2016, 4, 2685-2706.

5. Gorbatchuk V.V., Savelyeva L.S., Ziganshin M.A., Antipin I.S., Sidorov V.A. Russ. Chem. Bull. 2004, 53(1), 60-65.

6. Yakimova L.S, Ziatdinova R.V., Evtugyn V.G., Rizvanov I.K., Stoikov I.I. Russ. Chem. Bull. 2016, 65(4), 1053-1060.
7. Dong S., Zheng B., Wang F., Huang F. Acc. Chem. Res. 2014, 47, 1982-1994.

8. Vavilova A.A., Nosov R.V., Mostovaya O.A., Stoikov I.I Macroheterocycles 2016, 9, 294-300.

9. Vavilova A.A., Nosov R.V., Yakimova L.S., Antipin I.S., Stoikov I.I. Macroheterocycles 2013, 6, 219-226.

10. Puplampu J.B., Yakimova L.S., Vavilova A.A., Fayzullin D.A., Zuev Y.F., Stoikov I.I. Macroheterocycles 2014, 7, 337-344.

11. Nosov R.V., Stoikov I.I. Macroheterocycles 2015, 8, 120-127.

12. Nosov R.V., Stoikov I.I. Macroheterocycles 2014, 7, 345-350.

13. Puplampu J.B., Yakimova L.S., Vavilova A.A., Rizvanov I.K., Stoikov I.I. Macroheterocycles 2015, 8, 75-80.

14. Gorbatchuk V.V., Ziganshin M.A., Savelyeva L.S., Mironov N.A., Habicher W.D. Macromol. Symp. 2004, 210, 263-270.

15. Gorbatchuk V.V., Gatiatulin A.K., Ziganshin M.A., Gubaidullin A.T., Yakimova L.S. J. Phys. Chem. B 2013, 117, 14544-14556.

16. Jie K., Zhou Y., Yao Y., Huang F. Chem. Soc. Rev. 2015, 44 3568-3587.

17. Si W., Xin P., Li Z.T., Hou J.L. Acc. Chem. Res. 2015, 48, $1612-1619$.

18. Smolko V.A., Shurpik D.N., Shamagsumova R.V., Porfireva A.V., Evtugyn V.G., Yakimova L.S., Evtugyn G.A. Electrochim. Acta 2014, 147, 726-734.

19. Liz D.G., Manfredi A.M., Medeiros M., Montecinos R., Gómez-González B., Garcia-Rio L., Nome F. Chem. Commun. 2016, 52, 3167-3170.

20. Ogoshi T., Yamagishi T., Nakamoto Y. Chem. Rev. 2016, 116, 7937-8002.

21. Shurpik D.N., Padnya P.L., Evtugyn V.G., Mukhametzyanov T.A., Khannanov A.A., Kutyreva M.P., Stoikov I.I. RSC Adv. 2016, 6, 9124-9131.

22. Yakimova L.S., Shurpik D.N., Gilmanova L.H., Makhmutova A.R., Rakhimbekova A., Stoikov I.I. Org. Biomol. Chem. 2016, 14, 4233-4238

23. Shurpik D.N., Yakimova L.S., Makhmutova L.I., Makhmutova A.R., Rizvanov I.K., Plemenkov V.V., Stoikov I.I. Macroheterocycles 2014, 7, 351-357.

24. Shurpik D.N., Yakimova L.S., Rizvanov I.K., Plemenkov V.V., Stoikov I.I. Macroheterocycles 2015, 8, 128-134.

25. Yakimova L.S., Shurpik D.N., Stoikov I.I. Chem. Commun. 2016, 52, 12462-12465.

26. Boinski T., Szumna A. Tetrahedron 2012, 68, 9419-9422.

27. Ogoshi T., Aoki T., Kitajima K., Fujinami S., Yamagishi T., Nakamoto Y. J. Org. Chem. 2011, 76, 328-331.

28. Shurpik D.N., Padnya P.L., Basimova L.T., Evtugin V.G., Plemenkov V.V., Stoikov I.I. Mendeleev Commun. 2016, 25(6), 432-434.

29. Yushkova E.A., Stoikov I.I., Zhukov A.Yu., Puplampu J.B., Rizvanov I.K., Antipin I.S., Konovalov A.I. RSC $A d v$. 2012, 2, 3906-3919.

30. Stoikov I.I., Mostovaya O.A., Yantemirova A.A., Antipin I.S., Konovalov A.I. Mendeleev Commun. 2012, 22(1), 21-22.

31. Stoikov I.I., Yushkova E.A., Zhukov A.Y., Zharov I., Antipin I.S., Konovalov A.I. Tetrahedron 2008, 64, 7489-7497.

32. Ogoshi T., Hashizume M., Yamagishi T.A., Nakamoto Y. Chem. Commun. 2010, 46, 3708-3710.

33. Li C., Shu X., Li J., Chen S., Han K., Xu M., Jia X. J. Org. Chem. 2011, 76, 8458-8465.

34. Li H., Chen D.X., Sun Y.L., Zheng Y.B., Tan L.L., Weiss P.S., Yang Y.W. J. Am. Chem. Soc. 2013, 135, 1570-1576.

35. Ogoshi T., Masaki K., Shiga R., Kitajima K., Yamagishi T.A Org. Lett. 2011, 13, 1264-1266.

36. Cao D., Meier H. Asian J. Org. Chem. 2014, 3, 244-262.

37. Dube L.E., Patel B.A., Fagan-Murphy A., Kothur R.R., Cragg P.J. Chemical Sensors 2013, 3, 18 . 